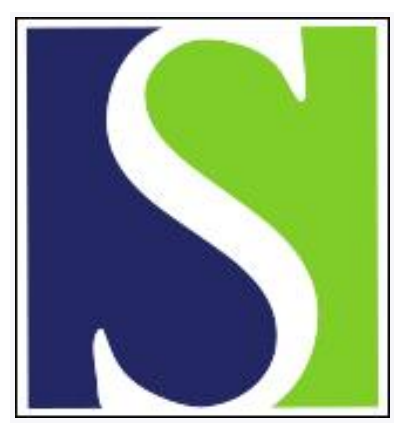

Scand J Work Environ Health 1986;12(6):594-602

https://doi.org/10.5271/sjweh.2097

Issue date: Dec 1986

Toxicokinetics of inhaled 2-butoxyethanol (ethylene glycol monobutyl ether) in man.

by Johanson G, Kronborg H, Naslund PH, Byfalt Nordqvist M

This article in PubMed: www.ncbi.nlm.nih.gov/pubmed/3823808

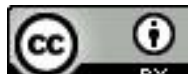




\title{
Toxicokinetics of inhaled 2-butoxyethanol (ethylene glycol monobutyl ether) in man
}

\author{
by Gunnar Johanson, MSc, Hans Kronborg, MSc, Per H Näslund, PhD, Marianne Byfält Nordqvist, \\ $\mathrm{PhD}^{1}$
}

JOHANSON G, KRONBORG H, NÄSLUND PH, BYFÄLT NORDQVIST M. Toxicokinetics of inhaled 2-butoxyethanol (ethylene glycol monobutyl ether) in man. Scand J Work Environ Health 12 (1986) $594-602$. Seven male volunteers were exposed to 2-butoxyethanol at the Swedish occupational exposure limit $\left(20 \mathrm{ppm}\right.$ or $\left.0.85 \mathrm{mmol} / \mathrm{m}^{3}\right)$ during light physical exercise $(50 \mathrm{~W})$ on a bicycle ergometer. The exposure took place in an exposure chamber and lasted $2 \mathrm{~h}$. Expired air was collected at regular time intervals for estimation of the respiratory uptake of the solvent. Arterialized capillary blood and urine were sampled during and after the exposure period and analyzed for 2-butoxyethanol and its metabolite butoxyacetic acid. A new sensitive method for analyzing 2-butoxyethanol in biological specimens is described. 2-Butoxyethanol was derivatized with pentafluorobenzoyl chloride and analyzed by gas chromatography with electron capture detection. The respiratory uptake of 2-butoxyethanol averaged $10.1 \mu \mathrm{mol} / \mathrm{min}$ or $57 \%$ of the inspired amount. The concentration in blood reached a plateau level of $7.4 \mu \mathrm{mol} / \mathrm{l}$. The apparent values of elimination half-time, mean residence time, total blood clearance, and steady-state volume of distribution were $40 \mathrm{~min}, 42 \mathrm{~min}, 1.2 \mathrm{l} / \mathrm{min}$ and $54 \mathrm{l}$, respectively. The amount of 2-butoxyethanol excreted in urine was less than $0.03 \%$ of the total uptake, while that of butoxyacetic acid ranged from 17 to $55 \%$.

Key terms: blood, butoxyacetic acid, cellosolve, exposure chamber, gas chromatography, glycol ether, physical exercise, urine.

Glycol ethers are widely used as solvents, detergents, or emulsifiers in a vast number of products, because of their excellent chemical and physical properties. During the last few years, evidence of reproductive hazards of the short-chained ethyleneglycol monoalkyl ethers (2-alkoxyethanols) in laboratory animals has encouraged the American Conference of Governmental Industrial Hygienists and several authorities in European countries, including Sweden, to adopt new and lower exposure limits for these compounds. The corresponding alkoxyacetic acid metabolite, or its glycine conjugate, has been found in urine from man or animal after the administration of 2-methoxyethanol, 2-ethoxyethanol, 2-isopropoxyethanol, and 2-butoxyethanol $(2,3,9,10,11,16)$. It appears that many of the toxic effects of the short-chained alkoxyethanols can be attributed to their acid metabolites $(2,7,15$, $17,19)$.

Toxicokinetic data on the glycol ethers are very scarce. It is therefore of great interest to investigate their toxicokinetics in man. The glycol ether 2-butoxyethanol (ethylene glycol monobutyl ether) was chosen for this study, as it is one of the most widely used (13). It appears to be much less hazardous than the shortchained alkoxyethanols with regard to reproductive effects $(19,23,24)$. No sensitive method to determine

\footnotetext{
1 Research Department, National Board of Occupational Safety and Health, S-171 84 Solna, Sweden.
}

Reprint requests to: Mr G Johanson, Research Department, National Board of Occupational Safety and Health, S-171 84 Solna, Sweden. the alkoxyethanols in biological specimens was available. Smallwood et al (21) reported the limits of detection for 2-methoxyethanol, 2-ethoxyethanol, and 2-butoxyethanol in blood to be $8.8,5.0$, and $4.0 \mu \mathrm{g} / \mathrm{g}$ $(116,56$, and $34 \mu \mathrm{mol} / \mathrm{kg})$, respectively. 2-Ethoxyethanol could not be detected in blood from workers in a field sampling survey, where the limit of detection was said to be less than $5 \mu \mathrm{g} / \mathrm{ml}(56 \mu \mathrm{mol} / 1)$ of blood (4). In a preliminary study, Johanson (12) reported 2-butoxyethanol plateau levels in the range of $5-15 \mu \mathrm{mol} / 1$ of blood when exposing resting volunteers to 2-butoxyethanol at 25-50 ppm. Before the toxicokinetics of 2-butoxyethanol could be determined at an appropriate exposure level, it was necessary to develop a more sensitive analytical method.

This paper presents (i) human data on the uptake, distribution, elimination, and urinary excretion of 2-butoxyethanol, as well as urinary excretion of its metabolite butoxyacetic acid, and (ii) a new method to determine 2-butoxyethanol in blood and urine by derivatization with pentafluorobenzoyl chloride.

\section{Subjects, materials and methods}

\section{Subjects}

Seven healthy men with an average age of 30 (range $21-38$ ) years, an average weight of 76 (range $65-85$ ) $\mathrm{kg}$, and an average height of 183 (range $176-192$ ) $\mathrm{cm}$ participated in the study (table 1). All the subjects stated no occupational exposure to solvents and low or no alcohol consumption. All were nonsmokers, except 
one, who smoked less than five cigarettes per day. None had suffered from any disease having a detrimental effect on the function of the respiratory and circulatory organs, and none were using any kind of drug at the time of the experiment. The subjects were told not to consume alcohol and to avoid activities, eg, painting, that could cause exposure to organic solvents during the preceding $24 \mathrm{~h}$ and throughout the experiment.

\section{Reagents and chemicals}

Pentafluorobenzoyl chloride and pentafluorobenzyl bromide were obtained from Pierce (Beijerland, Holland), heptanol (99\%) from Sigma (St Louis, Missouri), anhydrous diethyl ether (reagent grade) from Fisher (New Jersey), and tetrabutylammonium hydrogen sulfate from Labkemi (Solna, Sweden). All other commercially available chemicals were of analytical grade, purchased from Merck (Darmstadt, Federal Republic of Germany). All commercial chemicals were used without further purification.

Synthesis of butoxyacetic acid was carried out according to Budě inský et al (1). The procedure was, in short, as follows. To $25.3 \mathrm{~g}$ of sodium was added $280 \mathrm{ml}$ of butanol. Thereafter $47.3 \mathrm{~g}$ of chloroacetic acid was added during constant stirring at $60^{\circ} \mathrm{C}$, and the reaction mixture was refluxed for $90 \mathrm{~min}$. Water was added, and the excess of butanol was removed by azeotropic distillation. The residue was acidified with sulfuric acid $(5 \mathrm{~mol} / \mathrm{l})$. The organic phase was collected, and the water phase was extracted once with diethyl ether. After evaporation the residue was combined with the organic phase and distilled twice. The yield was $43.2 \mathrm{~g}$ or $65 \%$. The boiling point interval at $9 \mathrm{~mm} \mathrm{Hg}(1.2 \mathrm{kPa})\left(\mathrm{bp}_{9}\right)$ was $111-112^{\circ} \mathrm{C}$. The purity of the product was estimated by thin-layer chromatography on silica gel plates with ethylacetate-acetic acid-water $(70: 4: 4)$ as the eluent $\left(R_{f}=0.69\right)$. The plates were stained for organic material with sulfuric acid and scanned with a chromatogram spectrophotometer (Zeiss KM3). The purity was $99.1 \%$, calculated as $100 \times($ major peak area)/(total peak area). The synthesis of pentoxyacetic acid, to be used as the internal standard, was carried out as described for butoxyacetic acid. The yield was $44.8 \mathrm{~g}(61 \%)$, and the $\mathrm{bp}_{8.5}(1.1 \mathrm{kPa})$ was $122-123^{\circ} \mathrm{C}$. The identities of the alkoxyacetic acids were confirmed by gas chromatographic-mass spectrometric analyses (Hewlett-Packard 5985, electron energy $70 \mathrm{eV}$ ) after derivatization with pentafluorobenzyl bromide. The derivatization procedure and the gas chromatographic conditions were identical to those used in the determination of butoxyacetic acid in urine (described later). Prominent fragment ions of the pentafluorobenzyl ester of butoxyacetic acid were $m / e \quad 57 \quad(100 \%$, $\left.\mathrm{CH}_{3}-\left(\mathrm{CH}_{2}\right)_{3}-\right), 73\left(9.3 \%, \mathrm{CH}_{3}-\left(\mathrm{CH}_{2}\right)_{3}-\mathrm{O}-\right), 87(8.2 \%$, $\left.\mathrm{CH}_{3}-\left(\mathrm{CH}_{2}\right)_{3}-\mathrm{O}-\mathrm{CH}_{2}-\right)$, and $181\left(80 \%, \mathrm{C}_{6} \mathrm{~F}_{5}-\mathrm{CH}_{2}-\right)$. Prominent fragment ions of the pentafluorobenzyl ester of pentoxyacetic acid were $m / e$ $43(100 \%$, $\left.\mathrm{CH}_{3}-\left(\mathrm{CH}_{2}\right)_{2}-\right), 71\left(42 \% \mathrm{CH}_{3}-\left(\mathrm{CH}_{2}\right)_{4}-\right), 87(9.3 \%$, $\left.\mathrm{CH}_{3}-\left(\mathrm{CH}_{2}\right)_{4}-\mathrm{O}-\right)$, and $181\left(75 \%, \mathrm{C}_{6} \mathrm{~F}_{5}-\mathrm{CH}_{2}-\right)$.

\section{Exposure conditions}

The subjects were individually exposed to 2-butoxyethanol for $2 \mathrm{~h}$ at the Swedish exposure limit $\left(20 \mathrm{ppm}\right.$ or $\left.0.85 \mathrm{mmol} / \mathrm{m}^{3}\right)$ during light physical exercise $(50 \mathrm{~W})$ on a bicycle ergometer (table 2$)$. The exposure was conducted in an air-conditioned opensystem exposure chamber (volume $12 \mathrm{~m}^{3}$, air change 11 times $/ \mathrm{h}$, temperature $22-23^{\circ} \mathrm{C}$ ). The solvent vapor was dynamically generated at the fresh air side of the ventilation system by an evaporizer, ie, an electrically heated part of the ventilation tube equipped with an internal solvent injector. The solvent was supplied by a high-performance liquid-chromatography pump (Gilson 302). The fresh air was distributed through the perforated stainless steel ceiling of the chamber. The flow rate of waste air at the floor outlet was $20 \mathrm{~m}^{3} / \mathrm{h}$ greater than that of the inlet flow, in order to minimize leakage of solvent into the surrounding laboratory.

The concentration of 2-butoxyethanol in the chamber air was monitored at $9.078 \mu \mathrm{m}$ with $3.540 \mu \mathrm{m}$ as the reference wavelength by an infrared spectrophotometer (Miran 80, Foxboro) equipped with a $20-\mathrm{m}$ gas flow cuvette and controlled by a personal computer

Table 1. Estimates of physiological parameters in seven men exposed to 2-butoxyethanol at $20 \mathrm{ppm}$ for $2 \mathrm{~h}$ during light physical exercise $(50 \mathrm{~W})$ on a bicycle ergometer.

\begin{tabular}{|c|c|c|c|c|c|c|c|c|c|}
\hline \multirow[t]{2}{*}{ Subject } & \multirow[t]{2}{*}{$\begin{array}{c}\text { Age } \\
\text { (years) }\end{array}$} & \multirow{2}{*}{$\begin{array}{l}\text { Body } \\
\text { weight } \\
\text { (kg) }\end{array}$} & \multirow{2}{*}{$\begin{array}{l}\text { Body } \\
\text { height } \\
(\mathrm{cm})\end{array}$} & \multicolumn{2}{|c|}{$\begin{array}{l}\text { Pulmonary } \\
\text { ventilationa,b } \\
\left(1 \cdot \text { min }^{-1}\right)\end{array}$} & \multicolumn{2}{|c|}{$\begin{array}{l}\text { Respiratory } \\
\text { frequency } \\
\left(\min ^{-1}\right)\end{array}$} & \multicolumn{2}{|c|}{$\begin{array}{c}\text { Heart } \\
\text { rate }^{a} \\
\left(\min ^{-1}\right)\end{array}$} \\
\hline & & & & Mean & $S D^{c}$ & Mean & $S D^{C}$ & Mean & $\mathrm{SD}^{\mathrm{C}}$ \\
\hline $\begin{array}{l}1 \\
2 \\
3 \\
4 \\
5 \\
6 \\
7\end{array}$ & $\begin{array}{l}33 \\
33 \\
21 \\
30 \\
26 \\
38 \\
32\end{array}$ & $\begin{array}{l}75 \\
65 \\
76 \\
80 \\
79 \\
70 \\
85\end{array}$ & $\begin{array}{l}181 \\
179 \\
192 \\
182 \\
188 \\
176 \\
185\end{array}$ & $\begin{array}{l}19.8 \\
18.6 \\
21.1 \\
28.1 \\
22.1 \\
21.4 \\
26.9\end{array}$ & $\begin{array}{l}1.6 \\
0.9 \\
1.5 \\
0.9 \\
1.0 \\
1.1 \\
2.0\end{array}$ & $\begin{array}{r}17 \\
9 \\
13 \\
19 \\
14 \\
17 \\
18\end{array}$ & $\begin{array}{l}1 \\
0.3 \\
4 \\
2 \\
1 \\
1 \\
2\end{array}$ & $\begin{array}{r}82 \\
95 \\
84 \\
80 \\
102 \\
102 \\
76\end{array}$ & $\begin{array}{l}0.5 \\
7 \\
2 \\
3 \\
6 \\
2 \\
2\end{array}$ \\
\hline
\end{tabular}

a Recorded during the exposure period.

b Corrected for body temperature and pressure, and saturated water vapor pressure in the air (BTPS).

c Standard deviation $(\mathbf{N}=6)$. 
Table 2. Estimates of pharmacokinetic parameters for 2-butoxyethanol in seven men exposed to 2 -butoxyethanol at 20 ppm for $2 \mathrm{~h}$ during light physical exercise (50 W) on a bicycle ergometer.

\begin{tabular}{|c|c|c|c|c|c|c|c|c|c|c|c|c|c|}
\hline \multirow{3}{*}{ Subject } & \multirow{2}{*}{\multicolumn{2}{|c|}{$\begin{array}{c}\text { Inhaled } \\
\text { concentra- } \\
\text { tion } \\
\left(\mu \mathrm{mol} / \mathrm{m}^{3}\right)\end{array}$}} & \multicolumn{3}{|c|}{ Respiratory uptake } & \multirow{3}{*}{$\begin{array}{l}\mathrm{AUC}_{\mathrm{b}} \times 10^{3^{\mathrm{a}}} \\
\left(\mu \mathrm{mol} \cdot \mathrm{min} \cdot \mathrm{I}^{-1}\right)\end{array}$} & \multirow{3}{*}{$\begin{array}{l}\mathrm{AUMC}_{\mathrm{b}} \times 10^{\mathrm{b}} \\
\left(\mu \mathrm{mol} \cdot \mathrm{min}^{2} \cdot \mathrm{I}^{-1}\right)\end{array}$} & \multirow{3}{*}{$\begin{array}{l}t_{1 / 2}^{d} \\
(\mathrm{~min})\end{array}$} & \multirow{3}{*}{$r^{e}$} & \multirow{3}{*}{$n^{f}$} & \multirow{3}{*}{$\begin{array}{c}\overline{f g} \\
(\mathrm{~min})\end{array}$} & \multirow{3}{*}{$\underset{\left(1 \cdot \mathrm{min}^{-1}\right)}{\mathrm{CL}^{\mathrm{h}}}$} & \multirow{3}{*}{$V_{\text {ss, }}{ }_{(1)}^{i}$} \\
\hline & & & \multirow[t]{2}{*}{$\mu \mathrm{mol}$} & \multicolumn{2}{|c|}{$\%$} & & & & & & & & \\
\hline & Mean & $S D^{c}$ & & Mean & $S D^{c}$ & & & & & & & & \\
\hline $\begin{array}{l}1 \\
2 \\
3 \\
4 \\
5 \\
6 \\
7\end{array}$ & $\begin{array}{l}849 \\
857 \\
855 \\
831 \\
850 \\
842 \\
832\end{array}$ & $\begin{array}{r}17 \\
9 \\
12 \\
12 \\
15 \\
6 \\
9\end{array}$ & $\begin{array}{r}925 \\
937 \\
1205 \\
1643 \\
1142 \\
1131 \\
1491\end{array}$ & $\begin{array}{l}49.9 \\
54.0 \\
60.6 \\
63.9 \\
55.2 \\
57.2 \\
60.5\end{array}$ & $\begin{array}{l}3.2 \\
5.3 \\
3.0 \\
1.2 \\
2.2 \\
2.4 \\
0.9\end{array}$ & $\begin{array}{l}1.04 \\
1.08 \\
0.95 \\
0.96 \\
0.75 \\
0.96 \\
1.25\end{array}$ & $\begin{array}{l}0.93 \\
1.00 \\
0.98 \\
1.12 \\
0.74 \\
1.08 \\
1.26\end{array}$ & $\begin{array}{l}29.2 \\
50.5 \\
36.8 \\
63.4 \\
26.2 \\
49.1 \\
21.2\end{array}$ & $\begin{array}{l}0.92 \\
0.89 \\
0.90 \\
0.92 \\
0.96 \\
0.94 \\
0.99\end{array}$ & $\begin{array}{r}10 \\
11 \\
8 \\
11 \\
8 \\
8 \\
11 \\
8\end{array}$ & $\begin{array}{l}29.2 \\
31.9 \\
44.1 \\
57.7 \\
38.9 \\
52.0 \\
40.7\end{array}$ & $\begin{array}{l}0.89 \\
0.86 \\
1.27 \\
1.72 \\
1.51 \\
1.18 \\
1.19\end{array}$ & $\begin{array}{l}25.9 \\
27.6 \\
56.2 \\
99.1 \\
58.5 \\
61.2 \\
48.6\end{array}$ \\
\hline $\begin{array}{l}\text { Mean } \\
\text { SD }\end{array}$ & $\begin{array}{r}845 \\
10\end{array}$ & . & $\begin{array}{r}1210 \\
269\end{array}$ & $\begin{array}{r}57.3 \\
4.7\end{array}$ & . & . & . & $\begin{array}{l}39.5 \\
15.3\end{array}$ & . & . & $\begin{array}{l}42.0 \\
10.2\end{array}$ & $\begin{array}{l}1.23 \\
0.31\end{array}$ & $\begin{array}{l}53.9 \\
24.6\end{array}$ \\
\hline
\end{tabular}

a Total area under the blood concentration-time curve $\left(A \cup C_{b}={ }_{0} \int^{\infty} C_{b} d t\right.$, where $C_{b}$ is the concentration of 2-butoxyethanol in blood) was calculated with the trapezoidal rule (19).

b Total area under the first moment of the blood concentration-time curve $\left(A \cup M C_{b}={ }_{0} \int^{\infty} C_{b} \times t d t\right)$ was calculated with the trapezoidal rule.

c Standard deviation $(N=6)$.

d Elimination half-time of 2-butoxyethanol in blood was obtained from linear regression on the log-linear concentration-time curve of the entire decay phase.

e Regression coefficient.

f Number of samples with detectable amounts of 2-butoxyethanol during the decay phase.

9 Mean residence time $\left[\bar{t}=A U M C_{b} / A U C_{b}-T / 2\right.$, where $T$ is the exposure time (18)]

h Total blood clearance $\left[\mathrm{CL}_{b}=\right.$ dose/AUC $\mathrm{C}_{\mathrm{b}}$, where dose is substituted by the total respiratory uptake of 2-butoxyethanol (19)].

Steady-state volume of distribution $\left[\mathrm{V}_{\mathrm{ss}, \mathrm{b}}=\right.$ dose/AUC $_{\mathrm{b}} \times\left[A \cup M \mathrm{C}_{\mathrm{b}} / \mathrm{AUU} \mathrm{C}_{\mathrm{b}}-\mathrm{T} / 2\right]$ (18)].

(Apple III). Measurements with an aerosol meter (RAM-1，GCA/Environmental Instruments) confirmed that no significant amount of 2-butoxyethanol aerosol was present in the exposure chamber air prior to the experiment. Furthermore, the achieved 2-butoxyethanol concentration was in close agreement with the theoretical value one would obtain at complete evaporization of the injected solvent. The solvent concentration in the chamber was at the desired level when the volunteers entered. The fluctuations in the solvent concentration, expressed as one standard deviation, were less than $2 \%$ in all the experiments.

At six regular intervals during the exposure the expired air from each subject was collected in polyesterlaminated aluminum foil bags for approximately 4 $\min$. The volume of the expired air was measured with a balanced spirometer, and the solvent concentration was analyzed by infrared spectrophotometry as has already been described. The ventilation valve, tubes, bags, and gas cuvette were heated to approximately $50^{\circ} \mathrm{C}$, to avoid condensation of water and 2-butoxyethanol. The solvent uptake during each collection period was calculated as the difference between the amount of solvent in the inhaled and the exhaled air. The total solvent uptake for the whole exposure period was calculated by linear interpolation between the collection periods. Corrections were made for the differences in the partial pressure of water vapor between the inhaled and exhaled air. The temperature differences between the inhaled and the heated exhaled air were also accounted for. Heart rate, an electrocardiogram (chest-head leads), and respiratory frequency were recorded on a Mingograf 61 (Siemens-Elema,
Solna, Sweden). The respiratory frequency was sensored with a thermistor mounted in the mouthpiece of the ventilation valve.

\section{Blood analysis}

During the exposure period and $3 \mathrm{~h}$ afterwards blood samples were collected from a finger in heparinized capillary tubes for the analysis of 2-butoxyethanol. The capillary blood in the finger was arterialized by immersion of the hand in hot water prior to the sampling. The blood sample $(200 \mu \mathrm{l})$ was immediately transferred in a teflon-lined screw-cap vial containing $2 \mathrm{ml}$ of toluene, $0.2 \mathrm{ml}$ of an aqueous solution saturated at $50^{\circ} \mathrm{C}$ with sodium sulfate, and $10 \mu \mathrm{l}$ of an aqueous solution of heptanol $(0.43 \mathrm{mmol} / \mathrm{l})$, as the internal standard. After vigorous shaking, followed by centrifugation, the toluene phase was transferred to a new vial. To the vial were added $250 \mu \mathrm{l}$ of $0.4 \%$ pyridine in toluene and $4 \mu$ lof pentafluorobenzoyl chloride. The vial was kept at $50^{\circ} \mathrm{C}$ for $60 \mathrm{~min}$ in a shaking water bath, after which toluene and the excess of reagents were evaporated under nitrogen at $50^{\circ} \mathrm{C}$, and finally at low pressure [220 $\mathrm{mm} \mathrm{Hg}(29 \mathrm{kPa}), 10 \mathrm{~min}$ ]. The residue was dissolved in $1 \mathrm{ml}$ of $90 \%$ methancl and extracted with $2 \mathrm{ml}$ of hexane. The methanol phase was discarded and the hexane phase washed once more with 1 $\mathrm{ml}$ of $90 \%$ methanol. The hexane phase was then transferred to autosampler vials and stored at $-20^{\circ} \mathrm{C}$, awaiting gas chromatographic analysis. The derivatization steps followed the description by Duverger-van Bogaert et al (5) for the derivatization of styrene glycol, but volumes, times, and extractions were changed in order to increase the yield and reduce the number 
and size of interfering peaks in the gas chromatographic analysis.

Aliquots of $2 \mu \mathrm{l}$ were injected into the gas chromatographic column (Varian 3700 equipped with a ${ }^{63}$ nickel electron-capture detector, Varian 8000 autosampler and Vista $\mathbf{4 0 2}$ integrator). A fused silica capillary column [Oribond SE-30, $25 \mathrm{~m} \times 0.32 \mathrm{~mm}$ (inner diameter), $0.25-\mu \mathrm{m}$ phase layer] was used. Operating conditions were split injection $(1: 50)$, nitrogen as carrier and make-up gas [10 psi $(69 \mathrm{kPa})$ and 30 $\mathrm{ml} / \mathrm{min}$ ], injector temperature $220^{\circ} \mathrm{C}$, column temperature $150^{\circ} \mathrm{C}$, detector temperature $200^{\circ} \mathrm{C}$. The high injector temperature was found to decrease tailing of the solvent peak, while the comparatively low detector temperature increased the detector response. The concentration of 2-butoxyethanol was calculated from the 2-butoxyethyl pentafluorobenzoate : heptyl pentafluorobenzoate peak height ratio with spiked blood samples as the standard. All the samples were analyzed at least twice. A typical gas chromatogram is shown in figure 1. Concentrations of 2-butoxyethanol in blood down to approximately $0.1 \mu \mathrm{mol} / \mathrm{l}$ could be detected. The error of the method was estimated to be $11 \%$, expressed as the standard deviation divided by the average concentration in 25 samples spiked with 2-butoxyethanol $(10 \mu \mathrm{mol} / \mathrm{l})$.

\section{Urine analysis}

All urine was quantitatively collected during approximately $24 \mathrm{~h}$. The first sample was collected immediately before the volunteer entered the exposure chamber, and thereafter sampling was made at 2 -h intervals for $6 \mathrm{~h}$. The volunteer was then instructed to collect all urine in polyethene bottles, note the collection time, and store the bottles in his refrigerator until bringing them to the laboratory the next day, when the urine samples were immediately assayed for their 2-butoxyethanol concentration as has already been described. A fraction of each sample was frozen $\left(-70^{\circ} \mathrm{C}\right)$ until assayed for butoxyacetic acid.

The method used to determine butoxyacetic acid in urine was modified from Smallwood et al (21). To 1 $\mathrm{ml}$ of urine was added $100 \mu \mathrm{l}$ of hydrochloric acid (6 $\mathrm{mol} / \mathrm{l}$ ) and $10 \mu \mathrm{l}$ of an aqueous solution of pentoxyacetic acid ( $50 \%$ volume/volume) as the internal standard. The analyte was extracted into $1 \mathrm{ml}$ of methylene chloride. Then $1 \mathrm{ml}$ of an aqueous solution of sodium hydroxide $(0.2 \mathrm{~mol} / \mathrm{l})$ and tetrabutylammonium hydrogen sulfate $(0.1 \mathrm{~mol} / \mathrm{l})$ was added. After the addition of $100 \mu \mathrm{l}$ pentafluorobenzyl bromide and vigorous shaking, reaction took place at room temperature for $1 \mathrm{~h}$.

Aliquots of $1 \mu \mathrm{l}$ of the methylene chloride phase were injected into the gas chromatographic column. The same equipment as has already been described was used, except for flame ionization instead of electron capture detection. A fused silica, BP-10 column [SGE, Ringwood, Australia, $12 \mathrm{~m} \times 0.22 \mathrm{~mm}$ (inner diameter), $0.25 \mu \mathrm{m}$ phase layer] was used. Operating condi- tions were split injection $(1: 100)$; nitrogen as carrier and make up gas [ $10 \mathrm{psi}(69 \mathrm{kPa})$ and $30 \mathrm{ml} / \mathrm{min}]$; and the temperature of the injector, column and detector 220,170 , and $250^{\circ} \mathrm{C}$, respectively. The concentration of butoxyacetic acid was calculated from the pentafluorobenzylbutoxy acetate : pentafluorobenzylpentoxy acetate peak area ratio with spiked urine as the standard. A typical chromatogram is shown in figure 1. The error of the method was $7.6 \%$, calculated as the standard deviation of the difference between duplicates of 70 urine samples, divided by their average concentration.

\section{Calculations}

The half-times and slopes were calculated by linear regression on the log-linear blood concentration-time curve. Model-independent calculations of pharmacokinetic parameters were made according to Rowland \& Tozer (20), with correction for zero order input according to Perrier \& Mayersohn (18). To obtain the total area under the blood concentration-time curve $\left(\mathrm{AUC}_{\mathrm{b}}\right)$, areas for each experiment were calculated by the trapezoidal method from 0 to $200 \mathrm{~min}$. Thereafter, the area under the curve was determined as the

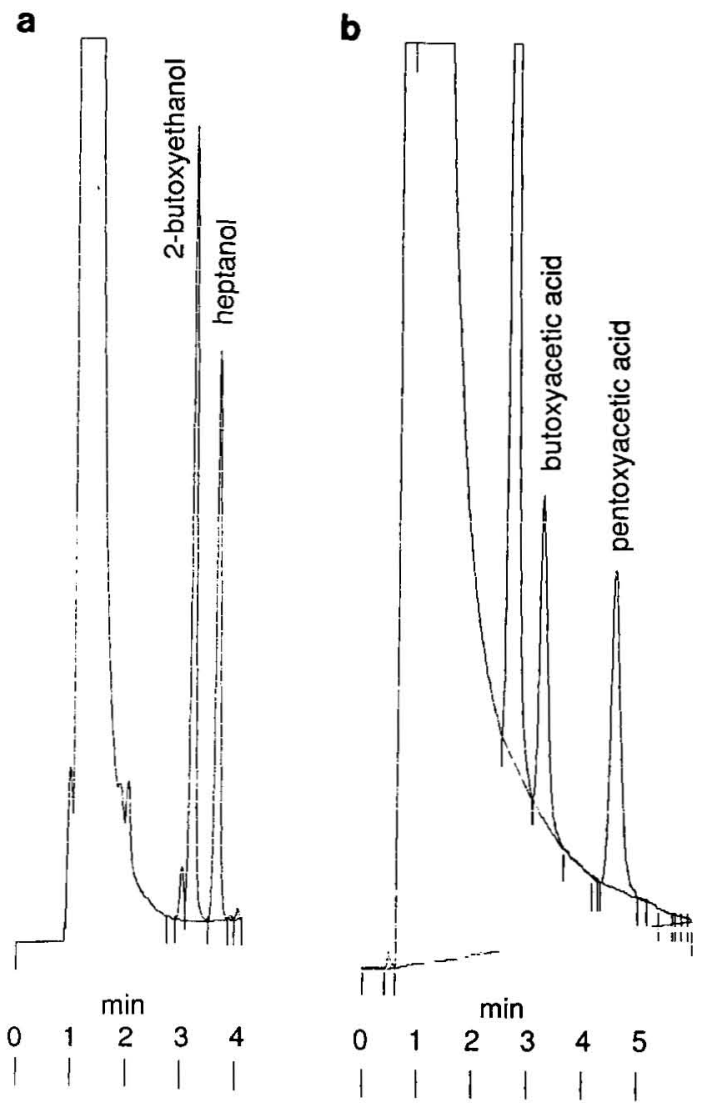

Figure 1. Gas chromatograms of the pentafluorobenzoyl derivatives of 2-butoxyethanol and its internal standard heptanol (a) and the pentafluorobenzyl derivatives of butoxyacetic acid and its internal standard pentoxyacetic acid (b). 
quotient between the individual concentration at 200 min and the slope. The latter was calculated as an average of all experiments with the use of the values from 200 to $360 \mathrm{~min}$. The use of individual slopes would possibly be less accurate, because at these low concentrations the 2-butoxyethanol peaks were close to the detection limit and in some cases were not detectable. The total area under the first moment of the blood concentration-time curve $\left(\mathrm{AUMC}_{\mathrm{b}}\right)$ was calculated by the same method. The mean value and one standard deviation are given, where applicable.

\section{Results}

None of the subjects complained of or showed any signs of adverse effects that could be related to the exposure to 2-butoxyethanol. Furthermore, no effects were observed in the electrocardiograms. During the exposure no consistent changes in pulmonary ventilation, respiratory frequency, or heart rate were seen (table 1). The retention of 2-butoxyethanol was fairly constant during the 2 -h exposure period (figure 2 ). The average respiratory uptake was 10.1 (SD 2.2) $\mu \mathrm{mol} / \mathrm{min}$ $(\mathrm{N}=7)$ or 57.3 (SD 4.7) \% of the inhaled amount.

The concentration of 2-butoxyethanol in blood rose rapidly, reaching an apparent plateau level within $1-2$ $h$ (figure 3 ). The decay after the exposure was similarly rapid, with a seemingly biphasic slope in a semilogarithmic plot (figure 4), although the data are too limited to permit the calculation of more than one slope constant. 2-Butoxyethanol could no longer be detected in the blood $2-4 \mathrm{~h}$ after the end of exposure. During the exposure, the average plateau level of 2-butoxyethanol in blood was 7.4 (SD 2.0) $\mu \mathrm{mol} / \mathrm{l}$ (N $=21$ ), which is significantly higher than the average concentration of $1.3(\mathrm{SD} 0.5) \mu \mathrm{mol} / \mathrm{l}(\mathrm{N}=7)$ in urine at the end of the exposure (figure 3 ). The average elimination half-time of 2-butoxyethanol was 40 (SD 15) min, while the mean residence time was 42 (SD 10) $\mathrm{min}$. The total blood clearance was 1.2 (SD 0.3) $1 / \mathrm{min}$, and the steady-state volume of distribution was 54 (SD 25) 1. Values for the individual experiments are reported in table 2. The half-time of 2-butoxyethanol in the urine was $1.36 \mathrm{~h}$ [correlation coefficient $(\mathrm{r})=0.88(\mathrm{~N}$ $=16$ )]. The total detected amount of 2-butoxyethanol excreted in the urine was less than $0.03 \%$ of the total uptake in all the experiments.

The excretion rate of butoxyacetic acid in urine (figure 5), as well as the concentration (not presented), varied more than 10 -fold between the extreme subjects. In general, there appeared to be an increase in the concentration and excretion rate during the first few hours, with maximums reached after $5-12$ and $2-10 \mathrm{~h}$, respectively. (The individual differences in excretion delay are clearly seen in figure 6.) The half-time of the decay of the concentration of butoxyacetic acid in urine, from $4 \mathrm{~h}$ after the end of exposure and thereafter, was 5.77 (SD 1.61) h. The total urinary excretion averaged $496 \mu \mathrm{mol}$ and ranged from 191 to $887 \mu \mathrm{mol}$. Relative to the uptake of 2-butoxyethanol, the excre-

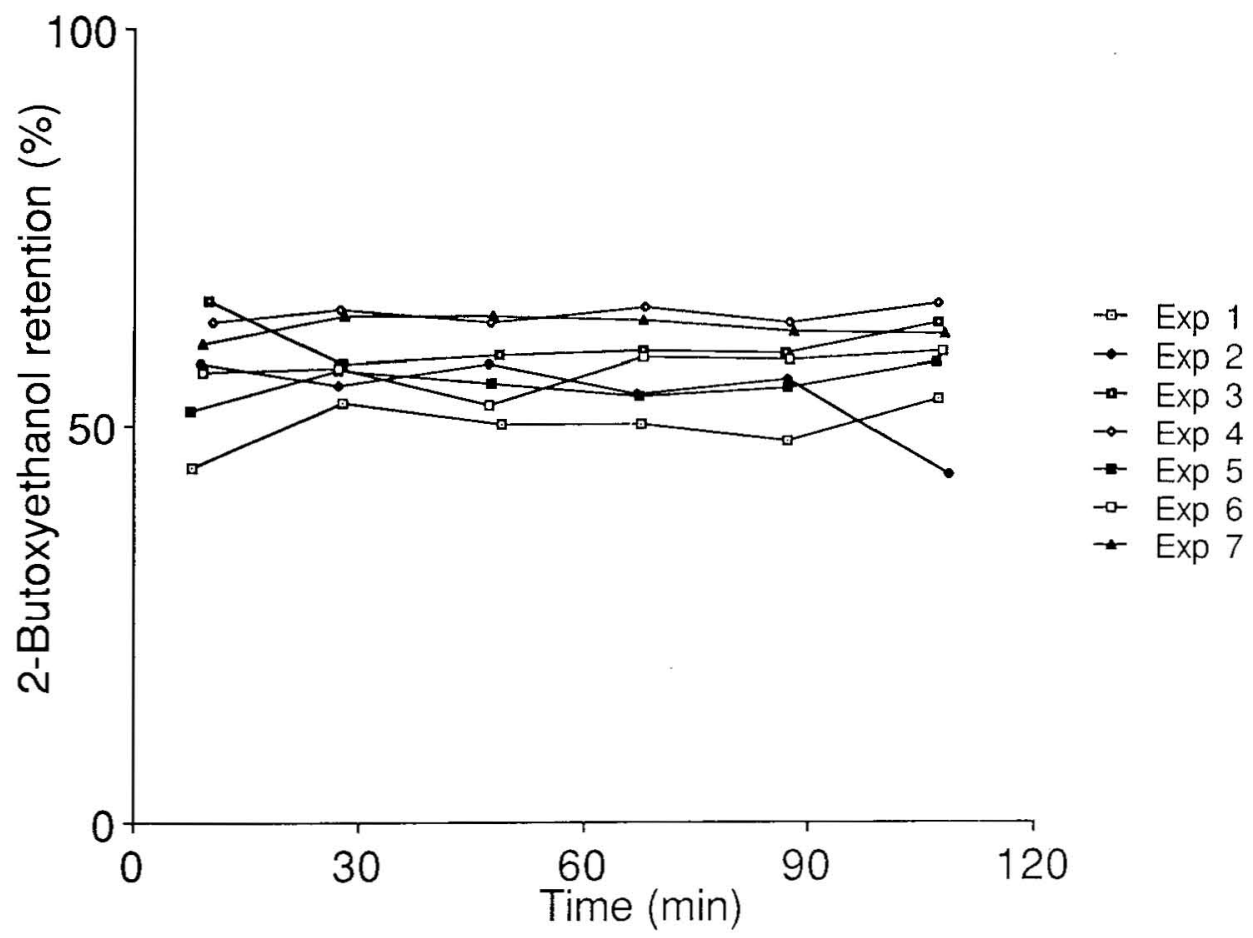

Figure 2. Time course of the respiratory retention of 2-butoxyethanol in seven men exposed to 2-butoxyethanol at $20 \mathrm{ppm}$ during light physical exercise $(50 \mathrm{~W})$ on a bicycle ergometer. 


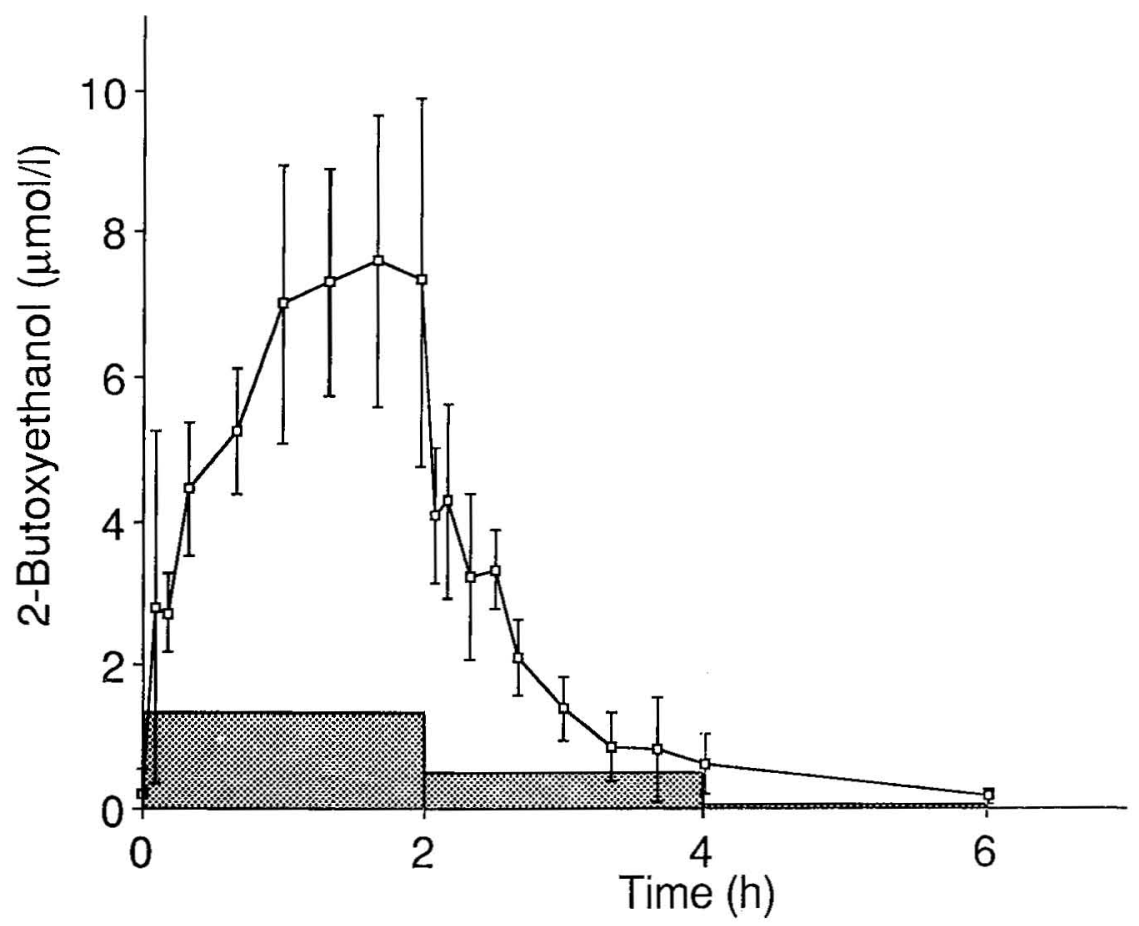

Figure 3. Average concentration of 2-butoxyethanol in the blood ( $\square$ ) and urine (shaded) from seven men during and after a 2-h exposure to 2-butoxyethanol at $20 \mathrm{ppm}$. The men were performing light physical exercise (50 W) on a bicycle ergometer. The vertical bars represent one standard deviation.

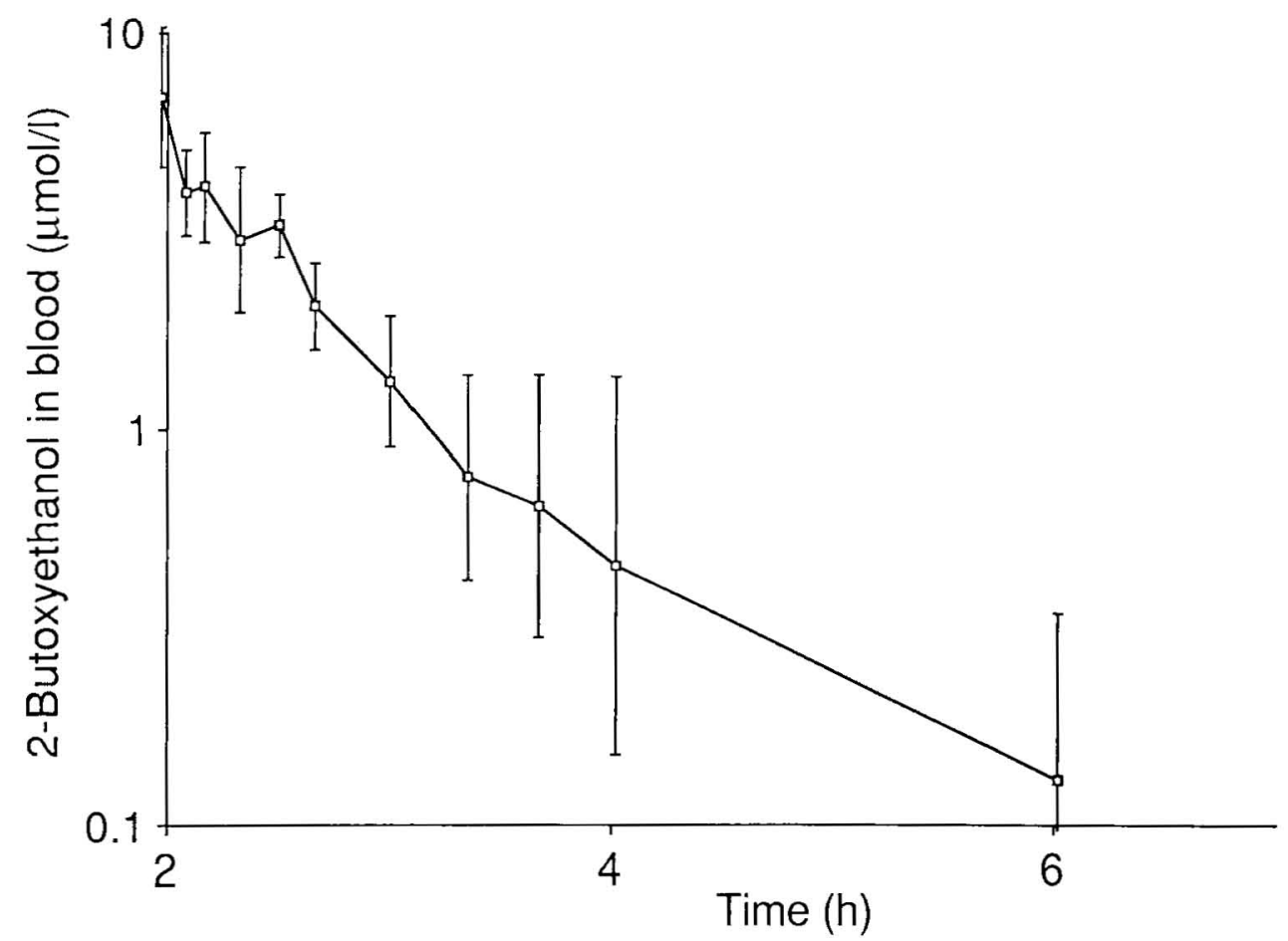

Figure 4. Concentration (geometric mean) of 2-butoxyethanol in the blood of seven men after a 2-h exposure to 2-butoxyethanol at $20 \mathrm{ppm}$ during light physical exercise $(50 \mathrm{~W})$ on a bicycle ergometer. Note the logarithmic scale of the ordinate. The bars represent one geometric standard deviation. 


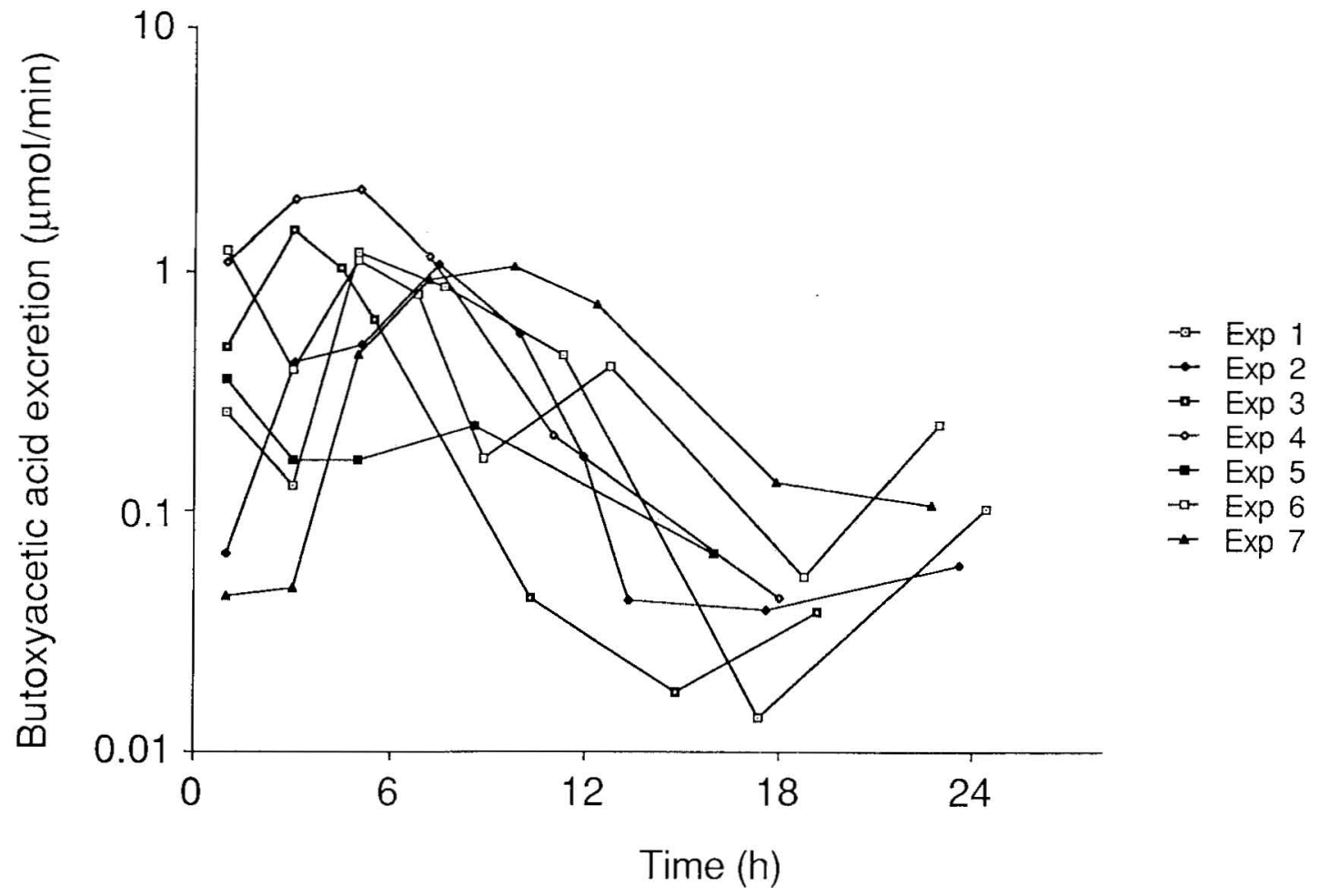

Figure 5. Renal excretion rate of butoxyacetic acid in seven men following a 2-h exposure of 2-butoxyethanol at $20 \mathrm{ppm}$ during light physical exercise $(50 \mathrm{~W})$ on a bicycle ergometer. Note the logarithmic scale of the ordinate.

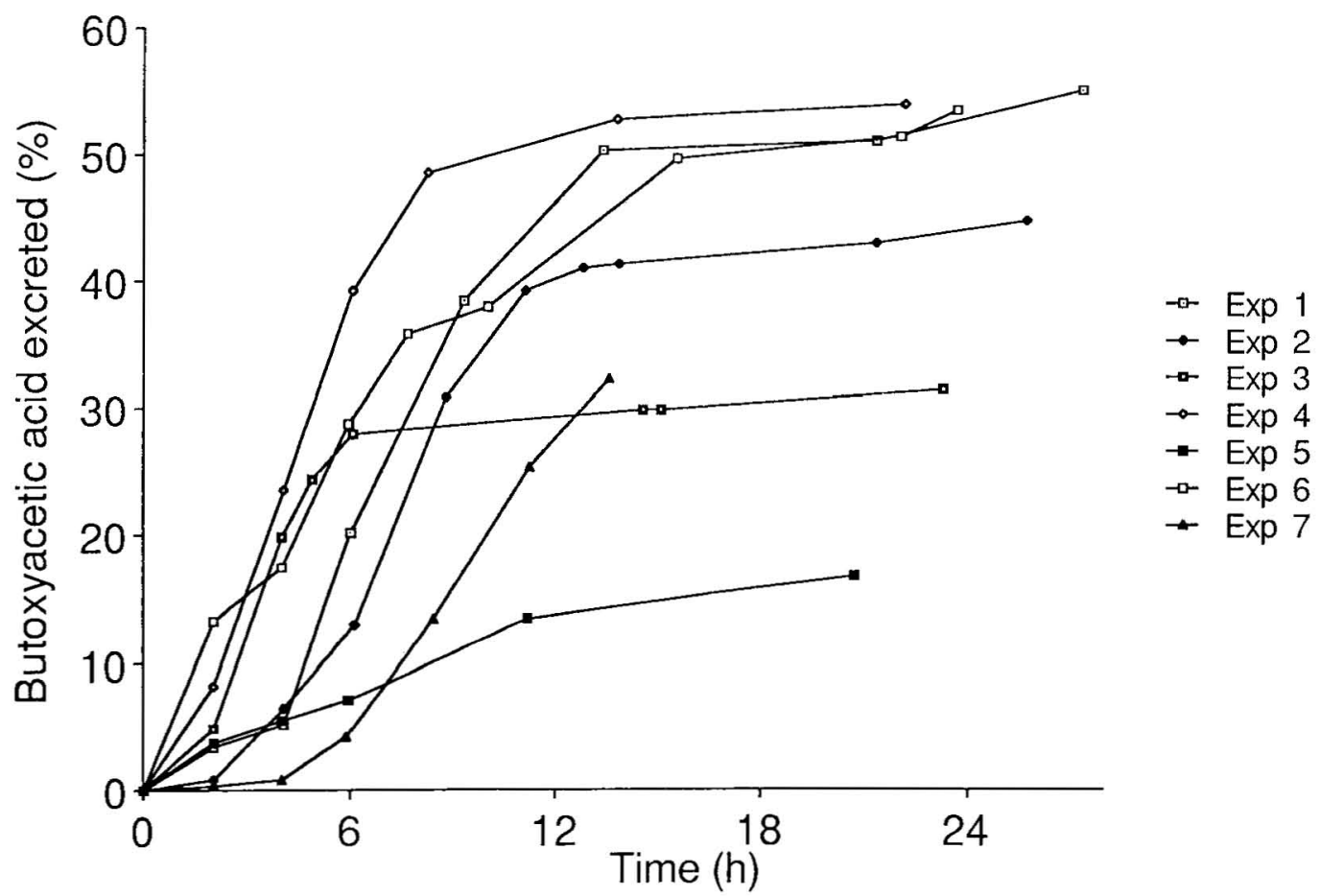

Figure 6. Cumulative excretion of butoxyacetic acid in the urine of seven men after a 2-h exposure to 2-butoxyethanol at 20 $\mathrm{ppm}$ during light physical exercise $(50 \mathrm{~W})$ on a bicycle ergometer. The excretion is expressed as the percentage of the total uptake of 2-butoxyethanol, on an equimolar basis. No urine sample of the next morning was obtained in experiment 7 . Hence total excretion could not be calculated for this subject. 
tion averaged $41.1 \%$ on an equimolar basis [range $15.1-55.0 \%,(N=6)]$. (See figure 6.)

\section{Discussion}

On the basis of the very high in vitro blood : air partition ratio (above 1000 , Johanson, unpublished observations), one would expect the respiratory retention of 2-butoxyethanol to be limited by the alveolar ventilation and approximate $80 \%$ at $50 \mathrm{~W}$, when the quotient between the physiological dead space and the tidal volume is 0.2 (8). However, the retention was about $57 \%$ in the present study. The explanation may be that 2-butoxyethanol is partly adsorbed on the surface of the respiratory airways during inhalation and desorbed during exhalation. Such a phenomenon has also been suggested for acetone (25). Nearly all of the inhaled propylene glycol monomethyl ether was retained in the upper respiratory tract in anesthetized, tracheotomized rats (22). Retention of solvent vapors in rabbit trachea in vitro has been shown for a number of solvents (6).

The plateau level of 2-butoxyethanol was about 7.4 $\mu \mathrm{mol} / \mathrm{l}$. This value is in agreement with the results of a preliminary study (12), when the differences in exposure level and work load are allowed for. The clearance value of about $1.2 \mathrm{l} / \mathrm{min}$ is also in agreement with the results of the mentioned study. Furthermore the clearance value is consistent with that obtained in perfused rat liver (14) when the size difference between the species is corrected for. Nonlinear (MichaelisMenten like) elimination kinetics of 2-butoxyethanol was demonstrated in the perfused rat liver. However, linear kinetics would be expected under the current exposure conditions, if extrapolating from rat to man.

The estimates of the volume of distribution is of the same order of magnitude as would be expected if 2-butoxyethanol distributed homogeneously in total body water. Preliminary studies (12) indicate that the solubility in fat (olive oil) and the binding to protein (bovine erythrocytes) are low. Also the high clearance rate and the low mean residence time suggest that the accumulation of unmetabolized 2-butoxyethanol in the body during usual occupational exposure is low. However, the possibility of specific binding of 2-butoxyethanol to certain tissues or tissue components should not be overlooked. The differences between the concentrations of 2-butoxyethanol in blood and urine samples collected during the same periods may indicate binding to blood components. In similar exposure experiments with acetone, the differences in concentrations between blood and urine were considerably smaller (25).

The analysis of the corresponding alkoxyacetic acid in urine has been suggested for the biological monitoring of exposure to 2-alkoxyethanols $(9,10,11,21)$. Considering 2-butoxyethanol, the results in the present study support this approach in that (i) the buto- xyacetic acid decay in urine is markedly slower than that of 2-butoxyethanol in urine or blood and (ii) the concentration of butoxyacetic acid in urine is far higher, and thus easier to detect, than that of 2-butoxyethanol in blood or urine. The present method cannot be used to detect butoxyacetic acid in blood. The excretion rate and the concentration of butoxyacetic acid in urine showed a large variability within, as well as between, individuals at any given time. In contrast the interindividual variation in the total excreted amount of butoxyacetic acid was comparatively smaller, although there was still a considerable variation. In biological monitoring, several urine samples from each individual would probably give more accurate information than would a single urine sample.

The relatively low recovery of butoxyacetic acid in the urine $(17-55 \%)$ suggests the formation of other metabolites. Hutson \& Pickering (9) found both isopropoxyacetic acid and its glycine conjugate ( $\mathrm{N}$-isopropoxyacetyl glycine) in the urine after dosing rats with 2-isopropoxyethanol. Similar findings have been made for 2-methoxyethanol and 2-ethoxyethanol (10, 17). The glycine conjugate of isopropoxyacetic acid hydrolyzed when treated with "hot acid" (9). It is as yet unclear to what extent N-butoxyacetyl glycine, if present, will hydrolyze under the milder acidic conditions used in the present study.

\section{Acknowledgments}

The authors wish to thank Ms J Gorczak for carrying out the gas chromatographic-mass spectrometric analysis, Dr E Milerad and Dr K Larsson for the medical examinations and the interpretation of the electrocardiograms, and Ms E Gullstrand, Ms E-M Nydahl, Ms E Lundgren, and Ms E Hansson for their excellent technical assistance.

\section{References}

1. Buděšinský Z, Bydžovský V, Kopecký J, Přrikryl J, Šváb A. Sulfonamidy $s$ protrahovanou antibakteriáln $i$ účin nosti: I 2-Sulfanilamido-alkoxypyrimidiny. Ceskošlov farm 10 (1961) 14-20. (English summary).

2. Carpenter CP, Pozzani UC, Weil CS, Nair JH, Keck GA, Smyth HF. The toxicity of butyl cellosolve solvent. Arch Ind Health 14 (1956) 114-131.

3. Cheever KL, Plotnick HB, Richards DE, Weigel WW. Metabolism and excretion of 2-ethoxyethanol in the adult male rat. Environ Health Perspect 57 (1984) $241-248$.

4. Clapp DE, Zaebst DD, Herrick RF. Measuring exposures to glycol ethers. Environ Health Perspect 57 (1984) 91-95.

5. Duverger-van Bogaert M, Noël G, Rollman B, Cumps J, Roberfroid M, Mercier M. Determination of oxide synthetase and hydratase activities by a new highly sensitive gas chromatographic method using styrene and styrene oxide as substrates. Biochim Biophys Acta 526 (1978) $77-84$.

6. Fiserova-Bergerova V. Physiological models for pulmonary administration and elimination of inert vapors and gases. In: Fiserova-Bergerova V, ed. Modeling of inha- 
lation exposure to vapors: Uptake, distribution and elimination. Volume I. CRC Press, Boca Raton, FL 1983, pp 73-100.

7. Foster PMD, Creasy DM, Foster JR, Gray TJB. Testicular toxicity produced by ethylene glycol monometh$\mathrm{yl}$ and monoethyl ethers in the rat. Environ Health Perspect 57 (1984) $207-217$.

8. Fridriksson HV. Early changes in respiratory function caused by occupational dust or tobacco smoking. University of Uppsala, Uppsala (Sweden) 1981. (Acta Universitatis Upsaliensis: Abstracts of Uppsala dissertations from the Faculty of Medicine 400).

9. Hutson DH, Pickering BA. The metabolism of isopropyl oxitol in rat and dog. Xenobiotica 1 (1971) 105-119.

10. Jönsson A-K, Pedersen J, Steen G. Ethoxyacetic acid and N-ethoxyacetylglycine: Metabolites of ethoxyethanol (ethylcellosolve) in rats. Acta Pharmacol Toxicol 50 (1982) $358-362$.

11. Jönsson A-K, Steen G. n-Butoxyacetic acid, a urinary metabolite from inhaled n-butoxyethanol (butylcellosolve). Acta Pharmacol Toxicol 42 (1978) 354-356.

12. Johanson G. Toxikokinetiska studier av 2-butoxietanol (butylglykol) [Toxicokinetic studies of 2-butoxyethanol]. Arbetarskyddsstyrelsen, Solna (Sweden) 1984. (Undersökningsrapport 39). (English summary).

13. Johanson G, Rick U. Förekomst av glykoletrar i kemiska produkter i Sverige [Occurrence of glycol ethers in chemical products in Sweden]. Arbetarskyddsverket, Stockholm 1986. (Arbete och hälsa 13) (English summary).

14. Johanson $G$, Wallén $M$, Byfält Nordqvist M. Elimination kinetics of 2-butoxyethanol in the perfused rat liver - Dose dependence and effect of ethanol. Toxicol Appl Pharmacol 83 (1986) 315-320.

15. Miller RR, Carreon RE, Young JT, McKenna MJ. Toxicity of methoxyacetic acid in rats. Fundam Appl Toxicol 2 (1982) $158-160$.

16. Miller RR, Hermann EA, Young JT, Landry TD, Calhoun LL. Ethylene glycol monomethyl ether and propylene glycol monomethyl ether: Metabolism, disposi- tion and subchronic inhalation toxicity studies. Environ Health Perspect 57 (1984) 233-239.

17. Moss EJ, Thomas LV, Cook MW, Walters DG, Foster PMD, Creasy DM, Gray TJB. The role of metabolism in 2-methoxyethanol-induced testicular toxicity. Toxicol Appl Pharmacol 79 (1985) 480-489.

18. Perrier D, Mayersohn M. Noncompartmental determination of the steady-state volume of distribution for any mode of administration. J Pharm Sci 71 (1982) $372-373$.

19. Rawlings SJ, Shuker DEG, Webb M, Brown NA. The teratogenic potential of alkoxy acids in postimplantation rat embryo culture: Structure-activity relationships. Toxicol Lett 28 (1985) $49-58$.

20. Rowland M, Tozer TN. Clinical pharmacokinetics: Concepts and applications. Lea \& Febiger, Philadelphia, PA 1980.

21. Smallwood AW, DeBord KE, Lowry LK. Analyses of ethylene glycol monoalkyl ethers and their proposed metabolites in blood and urine. Environ Health Perspect 57 (1984) $249-253$.

22. Stott WT, McKenna MJ. The comparative absorption and excretion of chemical vapors by the upper, lower, and intact respiratory tract of rats. Fundam Appl Toxicol 4 (1984) 594-602.

23. Tyl RW, Millicovsky G, Dodd DE, Pritts IM, France KA, Fischer LC. Teratologic evaluation of ethylene glycol monobutyl ether in Fischer 344 rats and New Zealand white rabbits following inhalation exposure. Environ Health Perspect 57 (1984) 47-68.

24. Tyler TR. Acute and subchronic toxicity of ethylene glycol monobutyl ether. Environ Health Perspect 57 (1984) $185-191$

25. Wigaeus E, Holm S. Ảstrand I. Exposure to acetone: Uptake and elimination in man. Scand $\mathrm{J}$ Work Environ Health 7 (1981) 84-94.

Received for publication: 21 March 1986. 